

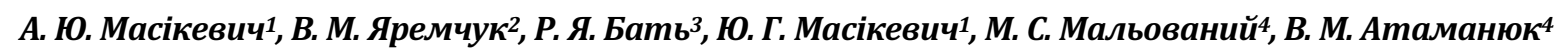

${ }^{1}$ Буковинський державний медичний університет, м. Чернівці, Украӥна

${ }^{2}$ Начіональний природний парк "Вижницький", смт Берегомет, Украӥна



${ }^{4}$ Національний університет "Львівська політехніка", м. Львів, Україна

\title{
УТИЛІЗАЦІЯ ДЕРЕВНИХ ВІДХОДІВ ШЛЯХОМ ВИГОТОВЛЕННЯ ПАЛИВНИХ ГРАНУЛ МЕТОДОМ ЕКСТРУЗІЇ
}

\begin{abstract}
Охарактеризовано специфічні особливості Покутсько-Буковинських Карпат, що визначають рівень їх екологічної безпеки. Оцінено екологічну небезпеку від неконтрольованого нагромадження деревних відходів у регіоні. Проаналізовано відомі технології гранулювання деревних відходів. Досліджено оптимальні умови сушіння деревних відходів у нерухомому шарі. Проведено експериментальні дослідження процесу сушіння відходів лісового господарства за різної висоти шару матеріалу та різної температури теплового агенту. Запропоновано спосіб екструзійного гранулювання композиції деревних відходів та в'яжучого натурального походження із отриманням паливних гранул. Показано перспективність використання сульфатного мила - в'яжучої речовини натурального походження, для покращення процесу грануляції деревних відходів. Запропоновано технологічне вдосконалення обладнання, що забезпечує рівномірний розподіл компонентів у процесі змішування в'яжучого та наповнювача в процесі гранулювання. Встановлено оптимальні умови отримання паливних гранул із деревним відходів екструзійним методом. Досліджено статистичну міцність та теплотворну здатність отриманих гранул, а також залежність між кількістю в'яжучого та концентрацією летких компонентів і коксовим залишком після спалювання гранули. Запропоновано принципову технологічну схему виробництва паливних гранул із деревних відходів екструзійним методом.
\end{abstract}

Ключові слова: Покутсько-Буковинські Карпати; деревинна біомаса; сучасні технології переробки; лігнінвмісні сполуки; екологічна безпека.

Вступ. За умов загострення в світі питання енергетичного забезпечення, використання деревної біомаси набуває особливої актуальності. В Україні наявний потужний енергетичний потенціал біомаси (Lakyda et al., 2011; Masikevych \& Masikevych, 2011). Важливе енергетичне місце серед біотичних відходів належить біомасі деревини. На 2015 р. біопаливо мало найбільшу питому вагу $(81,3 \%)$ у структурі виробництва відновлюваних джерел енергії (зокрема 59,6 \% припадало на деревинну біомасу). При цьому, внесок енергії з біопалива становив 2,5\% (1283 тис. т нафтового еквіваленту) загального постачання первинної енергії в Україні (Heletukha et al., 2015; Heletukha \& Zheliezna, 2017).

Відсутність недорогих доступних технологій утилізації відходів деревини призводить не тільки до енерге- тичних втрат, але й супроводжується цілим рядом екологічних проблем (забруднення водоймищ і грунтів у районі звалищ, розповсюдження збудників захворювань тощо), що потребують невідкладного вирішення.

Постановка проблеми дослідження. ПокутськоБуковинські Карпати (рис. 1) - специфічний за ландшафтними, кліматичними, соціально-економічними умовами регіон Східних Карпат. Це зовнішня смуга Українських (Східних) Карпат у межах Івано-Франківської та Чернівецької областей, що простягається з Північного Заходу на Південний Схід до кордону з Румунією майже на 75 км.

Незважаючи на подібність загалом карпатської гірської країни, для Покутсько-Буковинських Карпат характерні специфічні особливості, що визначають рі-

Інформація про авторів:

Масікевич Андрій Юрійович, канд. техн. наук, доцент, кафедра гігієни та екологіï. Email: masikevich.a@gmail.com; https://orcid.org/0000-0003-2862-9671

Яремчук Валерій Миколайович, здобувач, заступник директора. Email: vyzhpark@ukr.net; https://orcid.org/0000-0001-9175-3435

Бать Роман Ярославович, інженер. Email: mmal@lp.edu.ua

Масікевич Юрій Григорович, д-р біол. наук, професор, кафедра гігієни та екологіï. Email: yumasik@meta.ua; https://orcid.org/0000-0002-0324-1171

Мальований Мирослав Степанович, д-р техн. наук, професор, завідувач кафедри екології та збалансованого природокористування. Email: myroslav.mal@gmail.com; https://orcid.org/0000-0002-3868-1070

Атаманюк Володимир Михайлович, д-р техн. наук, професор, завідувач кафедри хімічної інженерії. Email: atamanyuk@ukr.net; https://orcid.org/0000-0002-8707-2319

Цитування за ДСтУ: Масікевич А. Ю., Яремчук В. М., Бать Р. Я., Масікевич Ю. Г., Мальований М. С., Атаманюк В. М. Утилізація деревних відходів шляхом виготовлення паливних гранул методом екструзії. Науковий вісник НлтУ України. 2019, т. 29 , № 1. C. 93-97.

Citation APA: Masikevych, Yu. A., Yaremchuk, V. M., Bat, R. Ya, Masikevych, Yu. G., Malovanyy, M. S., \& Atamanyuk, V. M. (2019). Wood Residues Recycling Using Extrusion Method of Wood-Pellets Production. Scientific Bulletin of UNFU, 29(1), 93-97. https://doi.org/10.15421/40290120 
вень екологічної безпеки цього регіону. Так, у рельєфі переважають низькогірські (до 800 м) та середньогірські (висота до 1483 м) ландшафти, схили вкриті переважно буковими та буково-ялицево-ялиновими лісами, вище 1150 м н.р.м. займають гірські луки, багато полонин, сіножатей, пасовищ, сільськогосподарських угідь, достатньо високий ступінь розораності земель (15$18 \%$ ), район густо заселений, клімат прохолодний, вологий (до 1000 мм опадів на рік). Перелічені особливості створили основу для інтенсивної господарської діяльності, що в комплексі з природними умовами сприяють зменшенню площі лісового покриву, руйнації грунтового покриву, поверхневому змиву, утворенню селевих явищ та забрудненню водотоків тощо в басейнах річок Черемош, Серет.

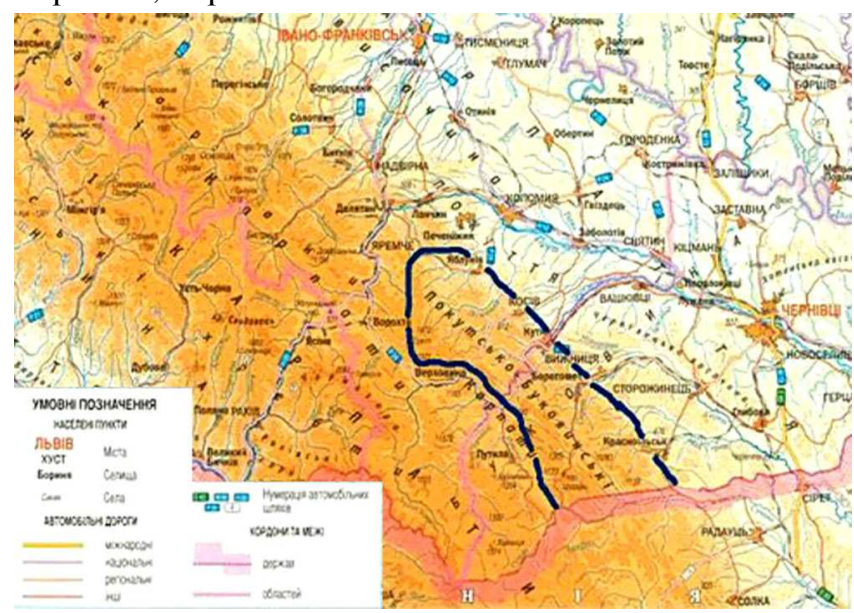

Рис. 1. Покутсько-Буковинські Карпати на карті України (https://uk.wikipedia.org/wiki/...)

За даними офіційної статистики (www.cv.ukrstat.gov.ua; Bilokon et al., 2016), основними лісогосподарськими районами Чернівецької обл., що входять до ПокутськоБуковинських Карпат, є Вижницький та Путильський гірські адміністративні райони, на які припадає 44,6 \% лісів та лісовкритих площ і 51,2 \% обсягів продукції лісового господарства. На кінець 2014 р. площа лісів Чернівецької обл., що надані у користування або власність, становила 247, тис. га, а залишки тільки первинних відходів деревини на лісосіках - 41,7 тис. м $^{3}(17720,4$ т), що становить $4,45 \%$ до загального підсумку. Треба зазначити, що цей регіон $є$ недостатньо вивченим в аспекті екологічної безпеки. Розроблення та використання нових сучасних технологій утилізації деревних відходів може мати істотний еколого-економічний ефект для регіону Покутсько-Буковинських Карпат.

Аналіз останніх досліджень і публікацій. Перспективним напрямком використання твердих відходів лісопильно-деревопереробного виробництва $€$ перероблення їх на технологічну тріску для целюлозно-паперової промисловості, виробництва деревних плит, гідролізу тощо (Bekhta, 1994; Bekhta \& Dombrovska, 2006; Basok et. al., 2007).

Але основну частину відходів, яка за різними даними становить до $40 \%$ (а це переважно тирса, стружка та кора), не використовують у технологічних цілях та можна використати як паливо. Розширене їх виробництво стримує низька транспортабельність та складність під час дозування та зберігання. Покращити ці властивості можна шляхом їх гранулювання (Lakyda et al.,
2011; Vandapalli \& Sudhagar, 2014; Heletukha \& Zheliezna, 2017).

До найпоширеніших методів гранулювання належать (Klymenko et al., 2017; Masan et. al., 2018):

- гранулювання методом пресування. Цими методом можна отримати продукцію із широким діапазоном компонентів, а також легко переводити установку на випуск гранул іншого сировинного складу. Під час гранулювання цим методом утворення агломерату відбувається під впливом сил молекулярного притягування. Також можливе сплавлення твердих частинок за умови високого тиску та температури в зоні деформації, хімічні взаємодії з утворенням нових сполук та гідростатичний тиск рідкої фази в капілярах;

- гранулювання в апаратах барабанного типу. Найбільшого поширення набули горизонтальні барабани, що обертаються. У таких барабанах під час зволоження першочергово утворюються пористі агломерати, які за умови обкатування ущільнюються та перетворюються в міцні сферичні гранули. Їх міцність та густина залежать від величини сил агломерації, вмісту в'яжучих частинок у гранулі. Для проведення процесу гранулювання потрібно забезпечити зближення частинок на таку відстань, на якій будуть чітко виражені капілярні, поверхнево-активні та адгезійні сили, а також сили притягування;

- гранулювання в шнеках-грануляторах. Процес відбувається за двома принципами: нашаруванням або агломерацією. Метод нашарування використовують у тих випадках, коли нема обмежень за об'ємом установки. У цьому випадку гранули круглі, гладкі та однакові за розміром. Другий метод агломерування, застосовують в тих випадках, коли є обмеження за об'ємом установки. За цим методом можна отримати круглі гранули із гладкою поверхнею, хоча не такі якісні, як за першим методом. Оптимальні умови гранулювання у шнеку-грануляторі визначаються складом та властивостями вихідних компонентів;

- гранулювання в дискових грануляторах. Утворення гранул на дискових грануляторах, так само як і в барабанних, відбувається за умови зволоження вхідної сировини та одночасного обкатування на днищі гранулятора. Під дією сил тертя, тяжіння та відцентрової сили матеріал щільно прилягає до днища та бортів гранулятора, що перешкоджає ковзанню;

- гранулювання методом екструзї. За цим методом матеріал попередньо обробляється в змішувачі, де під час інтенсивного перемішування набуває пластичних властивостей за рахунок додавання рідкої фази, нагрівання до температури плавлення. У подальшому ця маса під тиском продавлюється через спеціальну матрицю;

- гранулювання в киплячому шарі. Зміст процесу полягає в тому, що гранулювання із одночасним сушінням відбувається в робочому об'ємі апарата в потоці теплоносія або охолоджуючого агента, який проходить через газорозподільну решітку та створює киплячий шар частинок. Процес ускладнюється необхідністю ретельного очищення газового потоку, який виходить із апаратів, а також різна тривалість перебування частинок в апараті.

Постановка завдання. Метою досліджень було встановлення оптимальних умов утилізації деревних відходів шляхом виробництва паливних гранул методом екструзії.

Викладення основного матеріалу. Попередніми дослідженнями встановлено (Malovany et al., 2006), що перспективним $\epsilon$ використання для гранулювання деревних відходів методом екструзії в'яжучого натурального походження (основною частиною якого є лігнін, виварений із деревної маси в процесі отримання целюлози) - сульфатного мила. Для формування гранули потрібно здійснити ряд операцій, відображених у вигляді блок-схеми технології на рис. 2. 


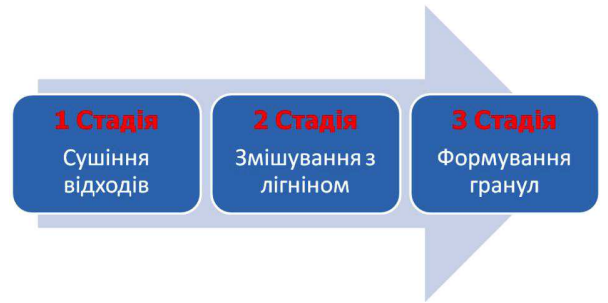

Рис. 2. Блок-схема технології отримання паливних гранул із відходів перероблення деревини

Зважаючи на те, що відходи деревини зберігаються під відкритим небом, їх вологість може досягати понад $70 \%$ у розрахунку на суху масу. Використання вологої сировини для виготовлення гранул є недоцільним у зв'язку із низькою теплотворною здатністю та неможливістю забезпечити міцність гранул. Окрім цього, зменшення кількості вологи, яка випаровується під час горіння, покращує умови експлуатації металічних елементів печі (за рахунок зменшення інтенсивності їх корозії). Тому для подальшого використання відходів деревини, як сировини для виготовлення гранул, їх необхідно висушити до вологості нижче $10 \%$ у розрахунку на суху масу. Ми запропонували проводити процес сушіння відходів деревини в нерухомому шарі.

Для правильної організації технологічного процесу сушіння необхідно вивчити вплив швидкості теплового агента, його температури, товщини шару на процес сушіння відходів деревини. Ми здійснили експериментальні дослідження процесу сушіння відходів лісового господарства за різної висоти шару матеріалу та різної температури теплового агента.

Процес сушіння деревних відходів досліджували на експериментальній установці, зображеній на рис. 3 .

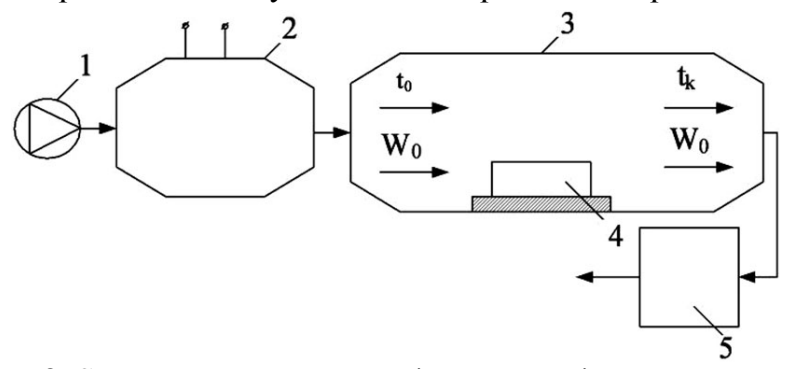

Рис. 3. Схема установки для дослідження сушіння деревних відходів: 1) вентилятор; 2) калорифер; 3) сушильна камера; 4) контейнер із наважкою; 5) система очищення

На рис. 4 зображено результати експериментальних досліджень впливу температури сушильного агента на кінетику сушіння деревних відходів. Можна побачити, що 3 підвищеним температури тривалість сушіння зменшується. Коли температура теплового агента становить $135^{\circ} \mathrm{C}$, то вологий матеріал досягає кінцевої вологості за 3900 c, із температурою теплового агента 60 ${ }^{\circ} \mathrm{C}$ - за 7200 с. Зрозуміло, що чим вища буде температура теплоносія, тим менша тривалість сушіння.

Однак підвищення температури призводить до зростання втрат тепла в навколишнє середовище та до перегрівання верхніх шарів матеріалу. Залежно від параметрів сушіння (висоти шару, температури), по-різному необхідно організовувати процес у промислових умовах. Встановлення залежності сушіння від технологічних параметрів теплового агента та висоти шару, є основою для розроблення конструкції сушильної установки. Проведено дослідження щодо залежності процесу сушіння деревних відходів від висоти їх шару. Встанов- лено, що оптимальними будуть такі умови, коли тривалість сушіння та енергетичні затрати будуть мінімізовані. Кінцева тривалість сушіння деревних відходів буде залежати як від висоти шару, так і від технологічних параметрів теплоносія (температури та швидкості руху теплоносія). За результатами досліджень встановлено, що оптимальна висота нерухомого шару деревних відходів становить $20 \cdot 10^{-3} \mathrm{M}$, а оптимальна температура теплового агента $-100{ }^{\circ} \mathrm{C}$.

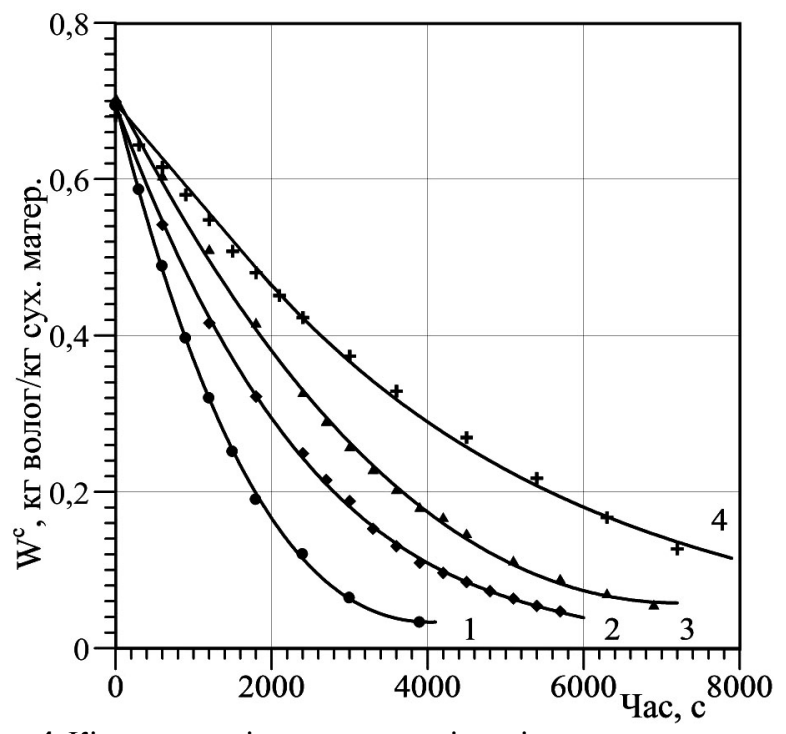

Рис. 4. Кінетика сушіння деревних відходів: висота шару $\left.\left.\left.\mathrm{H}=20 \cdot 10^{-3} \mathrm{~m}, \mathrm{v}_{0}=4,2 \mathrm{~m} / \mathrm{c}: 1\right) \mathrm{t}=135^{\circ} \mathrm{C}, 2\right) 100{ }^{\circ} \mathrm{C}, 3\right) 80^{\circ} \mathrm{C}$, 4) $60{ }^{\circ} \mathrm{C}$

На установці, зображеній на рис. 5, проводили дослідження для встановлення оптимального співвідношення між кількістю деревних відходів та в'яжучої речовини.

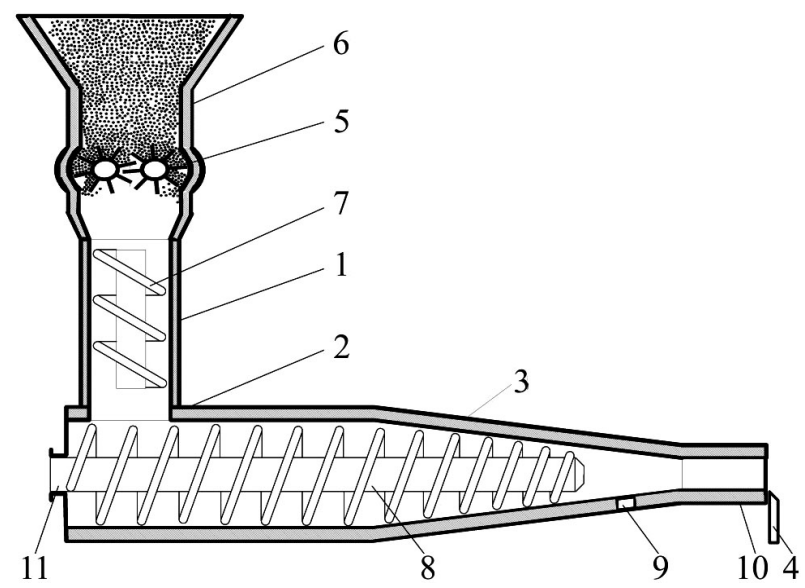

Рис. 5. Схема установки для формування паливних гранул із деревних відходів методом екструзії: 1) завантажувальний бункер; 2) циліндрична частина корпусу; 3) конічна частина корпусу; 4) різальний пристрій; 5) дозуючий пристрій; 6) підготовча камера; 7) дозуючий шнек; 8) шнек із транспортуючими, ущільнюючими та витискуючими лопатками; 9) дренажний отвір; 10) фільєра; 11) вал редуктора

Забезпечити рівномірний розподіл компонентів у процесі змішування в'яжучого та наповнювача $є$ надзвичайно складним процесом внаслідок невеликої кількості в'яжучого, його високої в'язкості та гігроскопічності деревних відходів. Неоднорідність суміші призводить до погіршення якості паливних гранул, їх крихкості як у місцях надлишку в'яжучого, так і в місцях його нестачі. Збільшення кількості в'яжучого призводить до погіршення якості отриманих гранул, зокрема зменшує 
їх міцність. Оснащення конічної частини корпусу дренажним отвором забезпечує видалення частини рідкого в'яжучого із суміші. Внаслідок зростання тиску в конічній частині корпусу в'яжучий компонент рівномірно розподіляється між дрібнодисперсними частинками деревних відходів, а його надлишок видаляється через дренажний отвір, що забезпечує високу міцність отриманих гранул та зменшує їх крихкість.

Надлишок в'яжучого зменшує тертя між сумішшю та робочими органами установки, що сприяє зниженню питомих витрат енергії на процес гранулювання, а також продовжує термін експлуатації обладнання. Виконання дренажних отворів на конічній частині дає змогу видаляти надлишок в'яжучого компонента із суміші. Завдяки дренажним отворам надлишок в'яжучого виводиться назовні, а тиск зменшується.

На експериментальній установці (див. рис. 5), формували паливні гранули із різним співвідношенням в'яжучої речовини у відношенні до деревних відходів, отримані паливні гранули пізніше досліджували.

Першим етапом досліджень було випробовування гранул на статичну міцність. Результати випробування подано в таблиці.

Таблиця. Результати випробувань на статичну міцність

\begin{tabular}{|c|c|}
\hline Вміст в'яжучого компонента в гранулі, \% & Тиск, кПа \\
\hline 35 & 0 \\
\hline 30 & 29 \\
\hline 25 & 39 \\
\hline 20 & 49 \\
\hline 16 & 39 \\
\hline 14 & 29 \\
\hline
\end{tabular}

Як видно із таблиці, під час застосування в'яжучого компонента міцність гранули зростає із збільшенням його вмісту. Але велика концентрація в'яжучого призводить до погіршення склеювання деревних частинок між собою, а це призводить до зменшення статичної міцності.

Результати експериментів із визначенням теплотворної здатності гранул наведено на рис. 6.

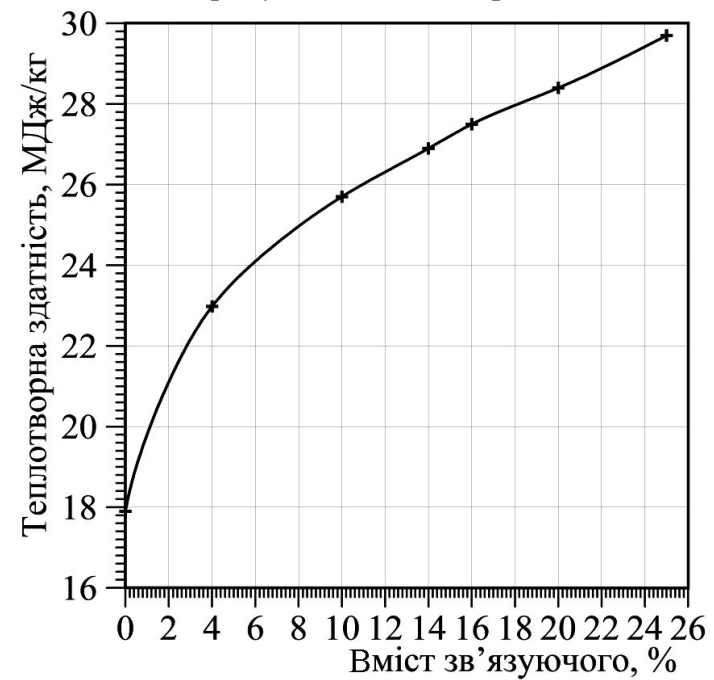

Рис. 6. Залежність теплотворної здатності гранул від відсоткового вмісту в'яжучої речовини

Дослідженнями також встановлено, що відсотковий вміст летких компонентів зростає із додаванням в'яжучої речовини. Це пояснюють тим, що в'яжуча речовина має більшу концентрацію летких компонентів. Тому із збільшенням вмісту в'яжучої речовини збільшується вміст летких компонентів у гранулі. Встановлено та- кож, що із додаванням в'яжучого вміст коксового залишку зменшується. Це пояснюють більшою здатністю до коксування деревних відходів, ніж в'яжучого.



Рис. 7. Принципова схема виробництва паливних гранул: 1) склад деревних відходів; 2) проміжний склад; 3) установка для подрібнення та сушіння; 4) місткість для зберігання в'яжучого компонента; 5) установка для гранулювання; 6) вібросито; 7) склад готової продукції; 8) піч

На рис. 7 зображено принципову схему процесу гранулювання. Відходи деревини привозять автотранспортом до складу деревних відходів 1, де їх сортують за гранулометричним складом та зберігають. У подальшому розділені відходи деревини надходять на проміжний склад 2. В установці 3 відбувається подрібнення деревних відходів та сушіння їх у нерухомому шарі. В установку для гранулювання 5 подається в'яжуча речовина та деревні відходи. Суміш, яка видавилась через дренажний отвір, повертається на початок установки 5. Готові гранули подаються на вібросито 6, для видалення дрібних частинок, які використовуються як паливо у печі 8, а придатні направляються на склад готової продукції 7. У подальшому відбувається упакування гранул та відвантаження споживачеві.

У пропонованій технології для формування гранул використовувався апарат, зображений на рис. 5. На нашу думку, використання цього апарата в пропонованій технології дасть змогу успішно вирішити проблему утилізації відходів перероблення деревини та відповідно зменшити екологічне навантаження від цих відходів на навколишнє середовище.

Висновки. Оцінено екологічну небезпеку від неконтрольованого нагромадження деревних відходів у регіоні Покутсько-Буковинських Карпат. Проаналізовано відомі технології гранулювання деревних відходів. Досліджено оптимальні умови сушіння деревних відходів у нерухомому шарі. Встановлено оптимальні умови попереднього сушіння сировини: висота шару $20 \cdot 10^{-3}$ м, температура теплового агента $100{ }^{\circ} \mathrm{C}$. За результатами аналізу даних проведених експериментів щодо співвідношення у композиції паливних гранул маси в'яжучої речовини і деревних відходів можна зробити висновок, що найпридатніша концентрація в'яжучої речовини, за умови екструзійного формування гранули, становить $20 \%$.

Це зумовлено: вищою теплотворною здатністю порівняно із деревними відходами; максимальною статичною міцністю гранул. Запропоновано принципову технологічну схему виробництва паливних гранул із деревних відходів екструзійним методом. 


\section{Перелік використаних джерел}

Basok, B. I., Obodovych, O. M., \& Lunina, A. O. (2007). Analysis of methods of recycling of plant material waste in the technologies of production of hydrolyzed alcohol, furfural and lignin. Industrial Heat Engineering, 29(6), 33-45. [In Ukrainian].

Bekhta, P. A. (1994). Production of chips for wood-particle boards. Kyiv: ISDO, 272 p. [In Ukrainian].

Bekhta, P., \& Dobrowolska, E. (2006). Thermal properties of woodgypsum boards. Holz als Roh- und Werkstoff, 64, 427-428. https://doi.org/10.07/s00107-005-0074-8

Bilokon, M. V., Avram, M. M., Bilokuchma, M. V., \& Artanovskyi, O. F. (2016). Regional report on the state of the environment in Chernivtsi region in 2015. Chernivtsi: Bukrek, 208 p. [In Ukrainian].

Geletuha, H. H., Zheleznaya, T. A., Kucheruk, P. P., Olejnik, E. N., \& Triboj, A. V. (2015). Bioenergy in Ukraine: State of the art and prospects for development. (Part 2). Industrial Heat Engineering, 37(3), 65-73. https://doi.org/10.31472/ihe.3.2015.08

Heletukha, H. H., \& Zheliezna, T. A. (2017). State of the art and prospects fo bioenergy development in Ukraine. Industrial Heat Engineering, 39(2), 60-64. https://doi.org/10.31472/ ihe. 2.2017.09

Klymenko, V. V. (Ed.), Kravchenko, V. I., Bokov, V. M. \& Hutsul, V. I. (2017). Technological bases of biofuel production from plant wastes and their composites. Kropyvnytskyi: PP "EkskliuzyvSystem", $162 \mathrm{p}$. Retrieved from: http://dspace.kntu.kr.ua/jspui/bitstream/123456789/ 6980/1/MonographyKlym.pdf. [In Ukrainian].
Lakyda, P. I., Vasylyshyn, R. D., Zibtsev, S. V., Lakyda, I. P., Heletukha, H. H., Zheliezna, T. A., \& Botcher, Kh. (2011). Energy potential of biomass in Ukraine. Kyiv: Vydannychyi tsentr NUBiP Ukrainy, 28 p. [In Ukrainian].

Malovanyi, M. S., Atamaniuk, V. M., \& Bat, R. Ya. (2006). Biocomposite based on waste wood and natural binder. Rynok instaliatsii, 11, 40-41. [In Ukrainian].

Masan, V., Burg, P., Visacki, V., \& Ondrej, P. (2018). Evaluation of fuel pellets as secondary product when pressing oil from grapevine seeds. Engineering for rural development jelgava. https://doi.org/10.22616/erdev2018.17.n311

Masikevych, A. Yu., \& Masikevych, Yu. H. (2011). Prospects for recycling wood waste in Chernivtsi region. Ecological Safety, 2(12), 63-66. [In Ukrainian].

Petrova, H. I. (Ed.). (2015). The environment of Chernivtsi region in 2014. Chernivtsi: Holovne upravlinnia statystyky u Chernivetskii oblasti, 155 p. Retrieved from: https://cv.ukrstat.gov.ua. [In Ukrainian].

Pokutsko-Bukovinian Carpathians. (2018). Retrieved from: https://uk.wikipedia.org/wiki/Pokutsko-Bukovynski_Karpaty. [In Ukrainian].

Sepúlveda, F. José, Arranz, J. Ignacio, Miranda, M. Teresa, Montero, I., \& Rojas, C. Victoria. (2018). Drying and Pelletizing Analysis of Waste from Cork Granulated Industry. Energies, 11, 109. https://doi.org/10.3390/en11010109

Vandapalli, V., \& Sudhagar Mani. (2014). Wet granulation of pine wood powders. Transactions of the ASABE, 57(4), 1211-1218. https://doi.org/10.13031/trans.57.10421

A. Yu. Masikevych', V. M. Yaremchuk', R. Ya. Bat ${ }^{3}$, Yu. G. Masikevych', M. S. Malovanyy4, V. M. Atamanyuk

${ }^{1}$ Bucovinian State Medical University, Chernivtsi, Ukraine

${ }^{2}$ Vizhnitsky National Park, Berehomet, Ukraine

${ }^{3} \mathrm{TzOV}$ "Lvivskyi beton", Lviv, Ukraine

${ }^{4}$ Lviv Polytechnic National University, Lviv, Ukraine

\section{WOOD RESIDUES RECYCLING USING EXTRUSION METHOD OF WOOD-PELLETS PRODUCTION}

The estimation of ecological danger from uncontrolled accumulation of wood waste in the Pokutsko-Bukovynian Carpathians is given. Specific natural features of the region of research that determine the level of their environmental safety are described. Objects of research are wood residues. Subject of the work is study of conditions for wood residues recycling using wood-pellets production by extrusion method. Authors compare main methods of wood residues granulation used in Ukraine and in foreign countries. Drying of wood residues in a stationary layer is proposed to improve the granulation process. For this purpose, influence of thermal agent's speed, its temperature, thickness of the layer on the process of wood residues drying is studied. Authors find out that increasing of temperature leads to rising of heat losses to the environment as well as to overheating of material upper layers. Optimal conditions for wood residues drying are established to minimize the energy consumption and drying duration. Optimal thickness of the stationary layer of wood residues is $20 \cdot 10^{-3} \mathrm{~m}$ and optimal temperature of thermal agent is $100{ }^{\circ} \mathrm{C}$. Authors show the benefit of natural lignin-containing compounds usage for the formation of wood pellets. Furthermore, it is found that an increase in the concentration of the binding agent leads to a deterioration of the bonding of wood particles between them, which causes a decrease in their static strength. Technological improvement of equipment for mixing of components in the process of wood pellets obtaining is offered. Equipping the conical part of the casing with a drainage hole ensures the removal of the excess of the binder component, which leads to a reduction in the fragility of wood-pellets. As a result, the optimal correlation between the amount of wood waste and the binder is determined. A framework flow chart is proposed for production of wood-pellet from wood residues using extrusion method. Usage of proposed technological approach will allow successfully solve the problem of wood waste disposal, decrease environmental pressure come from this waste and consequently increase level of mountain regions ecological safety.

Keywords: wood residues; extrusion; drying; granulation; wood-pellet; recycling. 